\title{
Breast Carcinoma in Younger Algerian Eastern Women: Epidemiological Profile in Series of 135 Cases
}

\author{
Sarra Henouda ${ }^{1, ~ *}$, Assia Bensalem ${ }^{2,3}$, Leila Rouabah ${ }^{1}$ \\ ${ }^{1}$ Laboratory of Molecular and Cellular Biology, Faculty of Natural Sciences and Life, University of Constantine, Constantine, Algeria \\ ${ }^{2}$ Medical Oncology Department, EH Didouche Mourad, Constantine, Faculty of Medicine, University 3 Constantine, Algeria \\ ${ }^{3}$ Faculty of Medicine, University of Constantine, Constantine, Algeria
}

Email address:

sara.henouda@yahoo.fr (S. Henouda)

\section{To cite this article:}

Sarra Henouda, Assia Bensalem, Leila Rouabah. Breast Carcinoma in Younger Algerian Eastern Women: Epidemiological Profile in Series of 135 Cases. Science Research. Vol. 3, No. 4, 2015, pp. 198-205. doi: 10.11648/j.sr.20150304.17

\begin{abstract}
Background: Actually, Breast cancer constitutes one of the most health problems in Algeria, and the leading cause of death among Algerian women. Breast cancer in young women is a rare form, but it has an aggressive behavior associated with a poor prognosis. Aims: this study focuses to report breast cancers phenotype in Algerian younger women. Material and methods: In order to better understand the determinants and tumor biology may explain earlier onset and aggressive breast cancers characteristics in Algeria from December 2011 to July 2014, 135 patients aged 40 years and under diagnosed with breast cancer were included in the study. Results: One hundred thirty-five women recorded, $65.9 \%$ patients were aged between 36-40 years. The mean age was 36.29 years. A significantly higher proportion of women were overweight or obese (62.9\%). $75.6 \%$ patientshad full-term pregnancy. $29.6 \%$ breast cancers were diagnosed during pregnancy or after childbirth. $34.1 \%$ patients had a family history. In $87.4 \%$ of cases the revealing sign was nodule self-examination. Stage II and III associated with nodal extension, higher pathological grade, HR positive, were predominant. Neo-adjuvant was administered to $17.8 \%$. 74.1\% patients underwent radical mastectomy using Patey technique with complete axillary dissection.40.7\% patients had distal metastases after diagnosis. The mean clinical tumor size was $4.88 \mathrm{~cm} .71 .1 \%$ of tumors were invasive ductal carcinoma.69.9\% patients had no family history. Conclusion: Breast tumors among Algerian young women are advanced with poor prognosis.
\end{abstract}

Keywords: Breast Cancer, Young Women, Aggressive, Prognosis and Advanced Form

\section{Introduction}

The definition of breast cancer among young women varies. Most studies are referring to women under either age 35,40 years or simply pre-menopausal as 'young' ${ }^{1}$. We've been focusing on women in their early 40 s and younger.

Breast cancer detected in young women is associated with an aggressive phenotype and poor prognosis than their older counterparts ${ }^{2,3,4,5,6}$. There are few studies examining breast cancer in women 40 years of age and younger, particularly in Algerian population. This study aimed to assess epidemiological profile of breast cancer in eastern Algerian.

Breast cancer is the most common female malignancy; accounting for about $23 \%$ of women malignant tumors, its incidence is particularly high for developed countries ${ }^{7}$. In young women, breast cancer incidence is low $(<17$ cases/ 100,000 women or $<6 \%$ of all breast cancers of all ages) ${ }^{8,9}$.
About $1 \%$ of patients with breast cancer are below 30 years and $6.5 \%$ between 30 and 40 years ${ }^{1}$. Breast cancer is the leading cause of death among women in Europe ${ }^{10}$. It is also considered as the first female cancer in Morocco ${ }^{11}$, Algeria ${ }^{12}$, Tunisia $^{13}$, and Jordan ${ }^{14}$ with a particularity affecting young woman. Age is considered a worse prognostic indicator ${ }^{6,15}$. Considering that breast cancers occur in younger women in our country, it is necessary to know their epidemiological features in women aged of 40 and under diagnosed with this tumor.

In Algeria, breast cancer is the first leading cancer for women, with 11.000 new cases/year. Epidemiological features of breast cancer appear to be different in developing countries compared to Western countries, with notably large proportions of young patients in Algeria, with an average age of 42 years old. (Representing 38-40\% of female cancers). Locally advanced disease is very common and total mastectomy is the most commonly performed surgery. 
5 to $10 \%$ of breast cancer cases can be attributed to major genetic factors such as BRCA1 and BRCA2, while this attribution is not yet well defined among Africans (including Algeria). To help determine the contribution of BRCA1 mutations to breast cancer in a North African population, we analyzed genomic DNA from breast cancer cases ascertained in Constantine (eastern city in Algeria).

\section{Materiel and Methods}

This is a descriptive cross-sectional retrospective epidemiological approach of women diagnosed or treated with breast cancer at the age of forty years old and less from December 2011 to July 2014 in Medical Oncology unit, University Hospital Dr BENBADIS, Constantine. It a census of 135 patients from eastern Algeria diagnosed at the age of forty years old. Data collection including several determining factors of the disease such as age of diagnosis, puberty, parity, lactation ... is performed during an interview for all patients in which they were interviewed on demographic, reproductive history, and other factors known or suspected breast cancer risk using a validated questionnaire. Participants provided many details. The patient's medical records are used to collect the phenotypic characteristics of tumors and treatment protocols. The selected data were entered and analyzed using SPSS 20.0 and Excel 2007 software enabling the analysis of results.

\section{Results}

One hundred thirty five women were identified in the study period. The patients mean age was 36.29 years (23-40). $65.9 \%$ of patients aged between 36 and 40 years. Most patients were housewives $(51.9 \%)$, married $(74.8 \%)$, overweight $(40 \%)$ or obese $(22.9 \%)$, had full-term pregnancy (75.6\%), used oral contraception $(58.5 \%)$ for an average duration of 4.03 years, performed breastfeeding (65.9\%), had a delay between the first signs of cancer and consultation varied from 1 and 6 months $(51.7 \%)$, presented with tumors more often in the left breast $(58.5 \%)$ and were located on the upper outer quadrant $(38.5 \%)$, treated with mastectomy (74.1\%). In our series, breast cancer is less likely among white patients $(41.5 \%)$. The menarche age was specified in 128 patients $(94.8 \%)$, which varies between 10 and 18 years with an average age of 13.69 years. About $23 \%$ of cases had their first menarche at the age of $14^{\text {th }}$. Age of first pregnancy was between 17 and 38 years with a mean age of 25.72 years. The predominant breast cancer revealed sign was selfexamination (87.4\%). Inflammatory cancers represented $13.3 \%$. Breast cancers were diagnosed during pregnancy among seventeen patients. From a total of 132 breast tumors (97.8\%), 80 and 47 tumors were grade II and III tumors respectively. The majority of tumors were classified T2 or T4. Younger patients' diseases were in most cases diagnosed in the advanced stages (III A or III B). Histological examination of the surgical specimen was found that invasive ductal carcinoma was the most common tumor $(71.1 \%)$, followed by invasive lobular carcinoma (10.4\%). 60\%, 56.3\% and $30.4 \%$ were estrogen, progesterone and human epidermal growth factor receptor-2 positive respectively. The triple negative tumors were found in $25.2 \%$ of patients. Seventynine tumors were associated with lymph node involvement $(\mathrm{N}+)$ and it was accompanied with capsular rupture in $14.1 \%$ of cases. Vascular and lymph emboli were present in $25.9 \%, 17 \%$ respectively. Axillary lymphadenopathy was absent in $40 \%$ of cases. Neo-adjuvant chemotherapy was administered to $17.8 \%$ of patients respectively. The majority of younger patients received a protocol type FEC+TxT or AC- TxT, with treatments number varies from 3 to 16 , and an average of six treatments. Nineteen patients underwent a second chemo line. $60 \%$ of cases had no hormonal therapy and $20 \%$ of patients were treated with tamoxifen. Sixty-five patients received adjuvant radiotherapy. Over evolution plan; 61 events were finding: six as recurrence which five were local and one Contralateral, fifty-five distal metastases were alive at mean follow-up of 5.04 months (0-18 months), with predominantly bone secondary location (21.5\%). A breast cancer family history in the 1st, 2nd or 3rd degree was found in 46 cases. (Study population characteristics among Algerian younger patients are enumerated in (Table 1).

Table 1. Characteristics of the Study Population.

\begin{tabular}{|c|c|}
\hline Characteristics & Rate (\%) \\
\hline \multicolumn{2}{|l|}{ Epidemiologic characteristics } \\
\hline \multicolumn{2}{|l|}{ Age at diagnosis (years) mean: $36.29(23-40)$} \\
\hline $20-25$ & 1.5 \\
\hline $26-30$ & 11.1 \\
\hline $31-35$ & 21.5 \\
\hline $36-40$ & 65.9 \\
\hline Urban environment & 25.9 \\
\hline Rural environment & 74.1 \\
\hline \multicolumn{2}{|l|}{ Profession } \\
\hline Housewives & 51.9 \\
\hline Liberal profession & 25.2 \\
\hline Official & 14.8 \\
\hline State cadre & 8.1 \\
\hline \multicolumn{2}{|l|}{ Marital Status } \\
\hline Married & 74.8 \\
\hline Single & 20.7 \\
\hline Divorced & 3.0 \\
\hline Widowed & 1.5 \\
\hline Patients Distribution according to BMI $\left(\mathrm{kg} / \mathrm{m}^{2}\right)$ & 3.0 \\
\hline Underweight & 34.1 \\
\hline \multicolumn{2}{|l|}{ Normal weight } \\
\hline Overweight & 40 \\
\hline Obesity & 22.9 \\
\hline \multicolumn{2}{|l|}{ Physical activity } \\
\hline Any activity & 89.6 \\
\hline Aerobics & 4.4 \\
\hline Others & 6 \\
\hline \multicolumn{2}{|l|}{ Screening } \\
\hline Yes & 3.7 \\
\hline No & 96.3 \\
\hline Alcohol & 00 \\
\hline Smoking & 00 \\
\hline \multicolumn{2}{|l|}{ Menarche age (years) } \\
\hline$\geq 11$ & 11.1 \\
\hline $12-14$ & 53.4 \\
\hline$\leq 15$ & 30.4 \\
\hline Age of first pregnancy (years) & \\
\hline
\end{tabular}




\begin{tabular}{|c|c|}
\hline Characteristics & Rate (\%) \\
\hline$>20$ & 9.7 \\
\hline $20-30$ & 45.8 \\
\hline $30-35$ & 15.4 \\
\hline$<35$ & 4.4 \\
\hline Patients had full-term pregnancy & 75.6 \\
\hline Nulliparity & 24.4 \\
\hline \multicolumn{2}{|l|}{ Total cumulative duration of breastfeeding (months) } \\
\hline 24 & 15.6 \\
\hline Less than 24 & 46.7 \\
\hline More than 24 & 3.7 \\
\hline \multicolumn{2}{|l|}{ Breast cancer diagnosis period } \\
\hline During pregnancy & 12.6 \\
\hline During breastfeeding & 17.0 \\
\hline Excluding these period & 70.4 \\
\hline \multicolumn{2}{|l|}{ First consultation delay (months) } \\
\hline$>3$ & 15.5 \\
\hline $3-6$ & 36.2 \\
\hline $6-12$ & 39.9 \\
\hline$<12$ & 17.7 \\
\hline \multicolumn{2}{|l|}{ Tumor characteristics } \\
\hline \multicolumn{2}{|l|}{ Histology } \\
\hline Invasive ductal carcinoma & 71.1 \\
\hline Invasive Lobular carcinoma & 10.4 \\
\hline Invasiveductal and lobular carcinoma & 7.4 \\
\hline Invasive ductal carcinoma + ductal carcinoma in situ & 3.7 \\
\hline Other & 7.4 \\
\hline \multicolumn{2}{|l|}{ Tumor size } \\
\hline Tx & 6.7 \\
\hline T0 & 1.5 \\
\hline $\mathrm{T} 1$ & 10.4 \\
\hline $\mathrm{T} 2$ & 28.9 \\
\hline $\mathrm{T} 3$ & 23.7 \\
\hline T4 & 28.9 \\
\hline \multicolumn{2}{|l|}{ Stage } \\
\hline 0 & 1.5 \\
\hline I & 5.9 \\
\hline II & 27.5 \\
\hline III & 43.7 \\
\hline IV & 13.3 \\
\hline Unknown & 8.1 \\
\hline \multicolumn{2}{|l|}{ Grade } \\
\hline Grade I & 0.7 \\
\hline Grade II & 59.3 \\
\hline Grade III & 34.8 \\
\hline Unknown & 2.2 \\
\hline \multicolumn{2}{|l|}{ Laterality } \\
\hline Right & 40.7 \\
\hline Left & 58.5 \\
\hline Bilateral & 0.7 \\
\hline \multicolumn{2}{|l|}{ Tumor localization } \\
\hline Upper outer quadrant & 38.5 \\
\hline Upper inner quadrant & 11.1 \\
\hline Entire breast & 8.1 \\
\hline Retroareolar & 6.7 \\
\hline Other & 29.6 \\
\hline \multicolumn{2}{|l|}{ Human epidermal growth factor receptor-2 } \\
\hline Positive & 30.4 \\
\hline Negative & 69.6 \\
\hline \multicolumn{2}{|l|}{ Oestrogen receptor status } \\
\hline Positive & 60.0 \\
\hline Negative & 40.0 \\
\hline \multicolumn{2}{|l|}{ Progesterone receptor status } \\
\hline Positive & 56.3 \\
\hline Negative & 43.7 \\
\hline \multicolumn{2}{|l|}{ Lymph node status } \\
\hline $\mathrm{N}+$ & 58.5 \\
\hline $\mathrm{N}-$ & 34.8 \\
\hline
\end{tabular}

\begin{tabular}{|c|c|}
\hline Characteristics & Rate (\%) \\
\hline Unknown & 6.7 \\
\hline \multicolumn{2}{|l|}{ Axillary lymphadenopathy } \\
\hline Unilateral & 54.1 \\
\hline Bilateral & 5.9 \\
\hline None & 40.0 \\
\hline Fixed & 23.0 \\
\hline Mobile & 37.0 \\
\hline Unknown & 40.0 \\
\hline \multicolumn{2}{|l|}{ Treatment characteristics } \\
\hline \multicolumn{2}{|l|}{ Surgery } \\
\hline Mastectomy & 74.1 \\
\hline Lumpectomy & 9.6 \\
\hline Bilateral mastectomy & 0.7 \\
\hline Other & 15.6 \\
\hline Radiation & 48.1 \\
\hline Yes & 51.9 \\
\hline \multicolumn{2}{|l|}{ No } \\
\hline \multicolumn{2}{|l|}{ Chemotherapy } \\
\hline Neoadjuvant & 17.8 \\
\hline Adjuvant & 71.1 \\
\hline \multicolumn{2}{|l|}{ Hormonal therapy } \\
\hline No & 60.0 \\
\hline TAM & 20.0 \\
\hline Nolvadex+Zoladex & 16.3 \\
\hline Zoladex & 2.2 \\
\hline \multicolumn{2}{|l|}{ Outcomes } \\
\hline Distal metastases & 40.7 \\
\hline Bone secondary location & 21.5 \\
\hline Lung secondary location & 5.2 \\
\hline Recurrence & 4.4 \\
\hline Local and & 3.7 \\
\hline Contralateral & 0.7 \\
\hline Discussion & \\
\hline
\end{tabular}

The increase breast cancer incidence in the last twenty years has been observed in world population ${ }^{16}$. In Lebanon and France, breast cancer is the most common cancer with a high incidence among women ${ }^{17,18,}{ }^{19}$. Worldwide, breast cancer estimation was more than 1.4 million new cases with 460,000 deathsin $2008^{20}$. In African countries, in general, Breast cancer is the second leading cause of death in women after cervical cancer ${ }^{21}$. In Algeria, in 2008, 7500 new breast cancer cases diagnosed each year with over 3500 deaths ${ }^{20}$. Breast cancer among women under $40^{\text {th }}$ is the most frequently cancer; it represents 30 to $40 \%$ of female cancers ${ }^{6,22,23}$. In the United States the breast cancer prevalence in women under $40^{\text {th }}$ is less than $5 \%{ }^{24} .10 \%$ of new breast cancer cases in France are in women under 40 years $^{25}$. Breast cancer in Algerian woman is a major public health problem that continues to increase largely, according to Pr. A. BENDIB, $12 \%$ of women with breast cancer are under 35 and $20 \%$ are under 40 years $^{26}$. Breast cancer is a rare disease in young women; however, it has attracted more interest because of its rapid evolution ${ }^{4}$. Breast tumors in younger women almost have a more aggressive biological behavior with poorer prognostic characteristics, higher risk of recurrence and mortality compared to older women ${ }^{27,28,29}$. Breast cancer prognosis has improved in these recent years, especially for the early stages, the best prognosis was found in women with an average age. Young age is not just the only factor responsible for the poor prognosis ${ }^{6,30,31}$. Breast cancer in our 
study among patients aged of 40 years and below is characterized by: overweight and obesity among nearly two third of patients $(63 \%)$. According ${ }^{17}, 30.9 \%$ are overweight or obese. This high rate is influenced by many factors including the sedentary lifestyle, change of diet pattern high in fat and low in fiber, westernized lifestyle of Algerian women. Prospective studies among premenopausal women showed that breast cancer increased risk associated with higher levels of endogenous estrogen ${ }^{32}$, authors show clears associations between obesity, estrogen serum concentrations and increased risk of developing breast cancer; the risk seems related to the exposure period ${ }^{33} .89 .6 \%$ of patients do not practice any physical activity. $4.4 \%$ of cases practice aerobic exercise as regular activity. Several studies have evaluated the impact of physical activity and body size on breast cancer risk; these factors are among the few suspected risk factors likely to change ${ }^{34,} 35$. In young women, the current data suggest a greatly reduced breast cancer risk associated with physical activity ${ }^{36}$.

The mean age of patients was 36.29 years (23-40).It is less that than found in ${ }^{37,38,27}$. However, A. KWONG et al and JL. GNERLICH et al, found a median age equal to 36 years, which in agreement with our result (ranges are respectively 24-39 and 11-39) ${ }^{39,4}$. This difference in the mean age noted between countries may be explained by the presence of genetic factors that may influence the age of early-onset breast cancer. Our data show that the dominant age group is those aged between 36-40 years, which represent $65.9 \%$ of, the total population. According to ${ }^{8}$, less than $1 \%$ of breast cancer patients were in the age group of $20-29,6.5 \%$ was in the age group of $30-39$, and $15.2 \%$ were in $40-49$ years age group. According ${ }^{29,40,41,42}$, age at diagnosis is an important prognostic factor particularly the young age is considered as poor prognostic indicator and a negative effect on survival and the relapse occurrence. However, studies ${ }^{43,44,45}$ do not report negative effect of young age on survival. Young women diagnosed with breast cancer typically receive more aggressive treatment than their older counterparts, which may explain their low survival rates. $41.5 \%$ of patients were blondes against $92.8 \%$ in series of ${ }^{8}$. According 9,46 , young black women under 40 had higher breast cancer incidence rate. $51.9 \%$ of patients were housewives. In our study this layer is often characterized by poverty, a lack of health information and a high nervousness. $74.8 \%$ of patients were married, followed by $20.7 \%$ were single. This is consistent with results of ${ }^{4}$. The husband is an important pillar, which plays a crucial role in the medico-psychological care of his wife. In $23 \%$ of subjects the age at menarche was specified to 14 years (mean 13.69 years; range 10-18). Similar results were found in this study ${ }^{47,48}$. Early puberty ( $\geq 11$ years) was founding in $11.1 \%$ of patients. According ${ }^{47}, 19.01 \%$ of cases were identified with early menarche. Increased breast cancer risk is strongly linked with early age at menarche ${ }^{33} .24 .4 \%$ of patients were nulliparous. This is consistent with result of $^{33} .75 .6 \%$ of cases had full term pregnancies versus $80 \%$ in the series of ${ }^{27}$. The long-term risk for women who have given birth to at least one child, however, remains lower than that of nulliparous ${ }^{48}$. In our study, the average age at first pregnancy was 25.72 years (17-38 years). This result is similar to that found by ${ }^{49} .25 .9 \%$ of subjects had a late pregnancy. The average pregnancies numbers was 3.54 (111 pregnancies). $\quad 6.7 \%$ were primiparous, $48.9 \%$ were pauciparous (2-4). 19.2\%were multiparous (5-8). Only one patient was multiparity (11 children). Early age at first fullterm pregnancy and multiparity lower breast cancer risk ${ }^{46}$. It is constantly reported in the literature ${ }^{50}$ that estrogen stimulation increases the breast cancer risk and consequently increasing its frequency; this risk increases with early menarche, nulliparity and late pregnancy. Diagnosed with breast cancer two years after giving birth to a child is associated with a low survival rate, regardless disease stage. $58.5 \%$ of patients have been taking oral contraceptives for an average duration of use was 6.81 years (0.5-18). Age of at the first time of using oral contraceptive was ranged from age 18 to 35 years (mean 25.95). Similar results were found in other studies ${ }^{48,17}$. Taking oral contraceptives greatly increases the breast cancer risk in young women ${ }^{46}$. The prevalence of breastfeeding practice among patients was $65.9 \%$ for an average period of36.51 months (1-144). According to ${ }^{47}, 66.9$ $\%$ of cases were practiced breastfeeding. Breastfeeding reduces the risk of invasive breast cancer, especially if they breastfeeds for longer period, even in BRCA1 carriers ${ }^{49}$. Breast cancer risk decreased by $7 \%$ for each new term pregnancy, and $4.3 \%$ for each year of breastfeeding regardless of ethnic origin, age, menopausal status, number children, age of women at first birth ${ }^{51} .74 .1 \%$ of the cases from the urban environment. It is characterized by sedentary lifestyle. Over young patients diagnosed with breast cancer in our series, $23 \%$ had breast disease before the cancerous lesion confirmation, $8.9 \%$ of these cases had a fibro adenoma.

Only one patient has been using chewing tobacco for 15 years until cancerous conformation. Active smoking and alcoholism were not found in our study population, which they are considered taboo in Algerian society.

Breast cancer was found in about $12.6 \%$ and $17 \%$ of pregnant and lactating women. Breast cancer is the most common type of cancer found during pregnancy. According to the literature, breast cancer association and pregnancy is a rare event which represents $0.2-3.8 \%$ of breast cancers ${ }^{25}$. A significant number of patients in our study have refused to end pregnancy. Diagnosed with breast cancer during pregnancy significantly increase the risk of breast cancer mortality $^{52}$. Left breast tumors were present in $58.5 \%$ of patients. This rate is similar to those of ${ }^{48,4}$. Most cancers were occurred in the upper outer quadrants, with more than $38.5 \%$, the same result was found in these studies ${ }^{13}$, ${ }^{48}$.Predominanceof breast cancer laterality can be explained by breastfeeding practices, the majority of our patients prefer to breastfeed their children on the left breast. Breast cancer bilateral form was found in only one patient in our series. This form is rare.

Breast self examination was the most revealer sign of cancer in our study $(87.4 \%)$. Identical were finding for ${ }^{13}, 48,47$, 53. According to ${ }^{54}$, breast self examination permits the 
detection of a $30 \%$ reduction in cumulative breast cancer mortality. The nipple retraction was found in $34.8 \%$ of cases. Axillary lymph nodes were present in $60 \%$ of cases. This rate is significantly higher than that found in this study ${ }^{27}$. $13.3 \%$ of patients were diagnosed three months after cancer symptom onset (mean: 8.27, 1-48 months). This result is in agreement with that of ${ }^{48}$. Lag time between onset of clinical symptoms and first diagnosis was more or less long and differs depending on the case, an extensive delay in consultation among breast cancer patients in this study was observed, it could be explained by the practice of traditional treatment before referral to the structure medical since a significant rate of women who believe that traditional medicine is more reliable on the one hand and on the other the fear of breast cancer in this younger age influencing its feminine prevents women to consult with a qualified physician since the onset of first sign. Breast cancer patients had relatively large tumor at diagnosis with an average size of $4.88 \mathrm{~cm}(0.3$ to $18 \mathrm{~cm})$. Younger women had tumors that were more likely to be higher ${ }^{4}$. According to ${ }^{5}$, the tumor size plays a major role in predicting survival in breast cancer patients. Given the lack of routine screening guidelines for women under $40^{\text {th }}$, it is not surprising that they are more likely to have palpable mass and tumors tend to be larger. Rate of breast cancer screening was very low among study subject $(3.7 \%)$. Inflammatory breast cancers were found in $13.3 \%$ of subjects. Inflammatory breast cancer is more likely to be diagnosed in women of African descent and young women $^{55}$. Inflammatory breast cancer is an especially aggressive type of breast cancer frequently raised in developing countries (access to care). The tumor was clinically classified in most cases $\mathrm{T} 4$ or $\mathrm{T} 2$.Similar results were observed in this series ${ }^{17}$. The tumor was classified N0 in $34.8 \%$ of cases, $\mathrm{N} 1$ in $25.2 \%, \mathrm{~N} 2$ in $23 \%$, N3 in $10.4 \%$ and $\mathrm{Nx}$ in $6.7 \%$. Against $38.13 \%$ of N2, $25 \%$ of N3, $23.75 \%$ ofN1and $13.12 \%$ of N0 in series of ${ }^{56}$. Stage Classification UICC was specified in $91.9 \%$ of patients, the common stages were IIIA, IIIB (16.3\% and $17 \%$ respectively). According to studies $4,39,56,57$, young women are more likely to be diagnosed at an advanced stage. This diagnostic delay is explained by the late consultation among the majority of patients, but also by the lack of routine screening system especially in young women at higher breast cancer risk, and the backwardness of mammography appointments in hospitals, which greatly influences the disease evolution. Breast cancer diagnosis in our service is based on the triad of clinical, radiological and histological. Given the breast cancer advanced stage, $74.1 \%$ of patients underwent radical surgery with axillary dissection according to Patey technique and $9.6 \%$ had received conservative surgery. This is consistent with the results of ${ }^{17,38,48}$. According to ${ }^{58}, 59 \%$ of cases were treated with mastectomy. Young patients diagnosed with breast cancer were more likely to be treated with mastectomy versus older women ${ }^{4,6}$, and 59 . In developed countries, most patients with breast cancer are treated by conservative treatment. The frequent use of Patey technique is explained primarily by the disease advanced stage and the lack of radiation therapy that is required in conservative surgery. Radical treatment reduces the risk of local recurrence. Histologically, the infiltrating ductal carcinoma represents $71.1 \%$ of cases in our series. This result is similar to those of ${ }^{27,37,38,48,56 ; 60}$.Carcinoma in situ was present in 1.4 $\%$ of cases. Ductal invasive carcinoma associated with carcinoma in situ represents $03.7 \%$ of cases. Ductal carcinoma in situ rate is lower compared to that reported by the literature since it quickly can progress to become invasive cancer because of the diagnosis delay observed amongst patients in our study. The grading of SBR found $59.3 \%$ grade II and $34.8 \%$ grade III. This is consistent with results of ${ }^{27 ;}$;1. Some series had results, which were different from ours $5,27,37$, and 38 . Studies show that young women diagnosed with breast cancer have high-grade tumors compared with their older counterparts $4,39,59$, and 61 . The lymph node invasion in our series was found in $58.5 \%$ of cases and in 68.6, 50, 52.5 and $67 \%$ according to $53,58,62$. Young women are diagnosed with tumors that are more likely to have positive lymph nodes ${ }^{4,59}$. Vascular emboli were found in $25.9 \%$ (35/78 cases) of cases in our series and in $25 \%$ and $30 \%$ of cases in series of ${ }^{48,53}$. Capsular rupture was found in $14.1 \%$ (19/107 cases) of patients and in $36.36 \%(8 / 22$ cas $)$ in the series of ${ }^{48}$. About $60 \%$ of tumors were estrogen receptor positive and $56.3 \%$ were progesterone receptor positive. This result is similar to that of ${ }^{38}$. The human epidermal growth factor receptor 2 was positive in $30.4 \%$ of cases. It varies from $30.2 \%$ according to ${ }^{37}$ to $30.6 \%$ according to ${ }^{38}$.The majority of tumors among Chinese young women were estrogen receptor and progesterone receptor positive, but they had a higher proportion of cerbB2-positive tumors $^{39}$. Young patients in our series had a positive rate of HR higher than expected, but similar to recent data reported in the literature. Neoadjuvant chemotherapy was administered to $17.8 \%$ and $71.1 \%$ of patients received adjuvant chemotherapy. $40 \%$ of cases were treated with hormonal therapy mainly type tamoxifen. It was administered in $20 \%$ of cases with positive hormone receptors, followed by $16.3 \%$ had received treatment consisting of TAM associated with zoladex. Actually, tamoxifen is the most important hormonal therapy administered to women with invasive breast carcinomas and hormone receptor-positive ${ }^{32}$. $27.4 \%$ of patients received targeted therapy with trastuzumab. Only $48.1 \%$ of patients received radiotherapy. Postoperative radiotherapy and chemotherapy amongst young patients diagnosed with breast cancer significantly reduce the rate of recurrence and mortality associated with this disease ${ }^{63,64,65}$.The largest shift observed in our series between the various therapeutic methods identified in breast cancer patients and the treatment received could be explained by the lack of centers for radiation generating appointments far reaching more than 20 months after the end of chemotherapy. This treatment is very expensive in private institutions. In our series, the rate of local recurrence was $3.7 \%$. The recurrence risk seems to be constant throughout life, so the young age at diagnosis is a cumulative risk of recurrence ${ }^{66}$. According to ${ }^{57}$, among 
young women, the high triple-negative rate leads to a high risk of recurrence. We found that $40.7 \%$ of subjects had secondary localization. Patients were diagnosed with bone predominant metastatic disease $(21.5 \%)$, followed by $5.2 \%$ of liver metastases. Metastases at diagnosis represent $13.3 \%$. $9.6 \%$ of metastases were bony. Breast cancer is rapidly changing in a metastatic table. According ${ }^{13}, 15.4 \%$ of tumors were metastatic at diagnosis, with $56 \%$ of bone metastases. $20.0 \%$ of patients received medical treatment before the diagnosis of cancerous lesions since their lesion considered as benign, while $16 \%$ was initially diagnosed with a benign disease in the series of ${ }^{27}$. Since mammography is not recommended or sensitive among young women because of the high density of breast tissue ${ }^{67}$, we must identify relevant preventive approaches. The overall survival without recurrence or metastasis in patients was 20.33 months (2-48 months). Median survival in the series of ${ }^{38}$ in women under $40^{\text {th }}$ was $243(88-300)$ months. It has been shown that the high tumor grade, lymph node status and the presence of distant metastases at diagnosis contribute to poor prognosis in women fewer than 40 with breast cancer ${ }^{3,68}$, and 69 . The death rate from breast cancer in our population during the study period was $3 \%$. This finding is similar to that reported by $^{47}$. Increase overall breast cancer incidence rate among Algerian younger women appears to be mainly the result of the increasing incidence of tumors expressing hormone receptor positive. We have observed that was an increased rate of tumors with hormone receptor positive among young women than previous years. Hormonal factors may explain the explosion of breast cancer that mostly affects young women. Studies suggest that nulliparity, early age at menarche, elevated BMI are associated with an increased risk of developing hormone-sensitive tumors. The lack of routine screening program for young women explains the tumor aggressive behavior in this age group.

A family history of breast cancer in the 1st, 2nd or 3rd degree was found in $34.1 \%$ of patients. According to the literature $^{70}, 20$ to $30 \%$ of women diagnosed with breast cancer have a family history, but only $5-10 \%$ of cancers have a genetic origin ${ }^{71}$.

\section{Conclusion}

The modern westernized lifestyle of Algerian young women influences significantly the increasing incidence of breast cancer in Algeria (decline in age at marriage, late age at first pregnancy, overweight and obesity, decreased breastfeeding period...). Cancer in Algerian young women imperatively requires particular attention to the diagnostic plans; therapeutic and psychological to help these women overcome the heavy burden of this disease. Young women are particularly vulnerable to emotional distress and psychosocial issues and should receive appropriate help. Those at high risk of developing breast cancer should be followed carefully. Algerian women need an increased awareness for breast cancer.

\section{Acknowledgement}

The authors thank all patients for their participation in this study.

\section{References}

[1] M. ESPIE, PH. COTTU. Cancer du sein de la femme jeune: problèmes et questions. Path Biol 2003; 51: 391-2

[2] D. COLAK, A. NOFAL, A. ALBAKHEET, M. NIRMAL, H. JEPREL, A. ELDALI, T. AL-TWEIGERI, A. TULBAH, D. AJARIM, OA. MALIK, MS. INAN, N. KAYA, BH. PARK, SM. BIN AMER. Department of Biostatistics, Epidemiology and Scientific Computing, King Faisal Specialist Hospital and Research Centre, Riyadh, Saudi Arabia

[3] M. CHUNG, HR. CHANG, KI. BLAND, HJ. WANEBO: Younger women with breast carcinoma have a poorer prognosis than older women. Cancer 1996, 77(1): 97-103

[4] JL. GNERLICH, AD. DESHPANDE, DB. JEFFE, A. SWEET, N. WHITE, JA. MARGENTHALER: Elevated Breast Cancer Mortality in Women Younger than Age 40 Years Compared with Older Women Is Attributed to Poorer Survival in Early-Stage Disease. Journal of the American College of Surgeons 2009, 208 (3): 341-347

[5] NS. EL SAGHIR, M. SEOUD, MK. KHALIL, M. CHARAFEDDINE, ZK. SALEM, FB. GEARA, et al. Effects of young age at presentation on survival in breast cancer, BMC Cancer. 2006; 6: 194, doi: 10.1186/1471-2407-6-194

[6] H .FREDHOLM, S. EAKER, J. FRISELL, L. HOLMBERG, I FREDRIKSSON, H. LINDMAN. Breast cancer in young women: poor survival despite intensive treatment, PLoS ONE. 2009; 4:e7695, doi: 10.1371/journal.pone.0007695

[7] DM. PARKIN, F. BRAY, J. FERLAY, P. PISANI: Global cancer statistics, 2002. Ca-a Cancer Journal for Clinicians 2005, 55(2): 74-108

[8] GM. SWANSON, CS. LIN: Survival patterns among younger women with breast cancer: the effects of age, race, stage, and treatment. J Natl Cancer InstMonogr 1994, 16:69-77

[9] LA. BRINTON, ME. SHERMAN, JD. CARREON, WF. ANDERSON: Recent Trends in Breast Cancer Among Younger Women in the United States. Journal of the National Cancer Institute 2008, 100(22):1643-1648

[10] F. MOLINIE et al. Incidence et pronostiques des cancers du sien découverts au cours et en dehors du programme de dépistage organize en loire -Atlantique (1991-2002). Revue d'epidémiologie et de santé publique. 2008. 56:41-49

[11] F. ABBASS, S. BENNIS, K. ZNATI, Y. AKASBI, J.K AMRANI, O. EL MESBAHI et A. AMARTI. Le profil épidémiologique et bilogique du cancer du sein à FèsBoulemane (maroc) EMHJ.Vol.17.No.12. 2011

[12] Y. BELKACEM, H. BOUSSEN, M. HAMDI CERIF, A. BENIDER, H. ERRIHANI, H. MRABTI, K. BOUZID, A. BENSALEM, S. FETTOUKI, M. BEN ABDALAH, L. ABID, J. GLIGOROV. Epidémiologie des cancers du sein de la femme jeune en Afrique du nord, 32es J de la SFSPM, Strasbourg, nov 2010 
[13] S. BEN AHMED, S. ALOULOU, M. BIBI, A. LANDOLSI, M. NOUIRA, L. BEN FATMA, L. KALLEL, O. GHARBI, S. KORBI, H. KHAIRI, C. KRAIEM. Pronostic du cancer du sein chez les femmes tunisiennes: analyse d'une série hospiyalière de 729 patientes. Santé publique 2002.Vol 14.N 13.PP 231-241

[14] AA. Abalkhail, HM ZAHAWI. NM ALMASRI. O K HAMEED. The role of young population structure in determining age distribution of breast cancer in Jordan. Journal of the Bahrain Medical Society; MajallatJam'īyat alAtibbā'al-Bahraynīyah 01/20 03; 15(1): 28-33

[15] E. Yildirim, Dalgic T, Berberoglu U: Prognostic significance of young age in breast cancer. Journal of Surgical Oncology 2000, 74(4):267-272.

[16] L. BOULANGER, D. VINATIER. Epidémiologie du Cancer du sein. CHRU de Lille. 2012

[17] H. GUENDOUZ, W. CHETIBI, A. ABDELOUAHAB, A. BENDIB. Cancer du sein de la femme de moins de 35 ans: étude rétrospective à propos de 612 cas. 32es journées de la SFSPM à Strasbourg nov. 2010

[18] American Cancer Society: Cancer Facts and Figures 2004. 2004,3, 10

[19] SM. ADIB, AA. MUFARRIJ, AI. SHAMSEDDINE, SG. KAHWAJI, P. ISSA, NS. EL-SAGHIR: Cancer in Lebanon: An Epidemiological Review of the American University of Beirut Medical Center Tumor Registry (1983-1994). Annals of Epidemiology 1998, 8: 46-51

[20] A. MAHNANE, M. HAMDI CHERIF, Epidémiologie du cancer du sein en Algérie. Actualités dans la prise en charge multidisciplinaires des cancers du sein en 2012.SAOM.2012

[21] GAETAN Mac GROGAN: Les néoplasies mammaires non invasives et invasives (le rôle du pathologiste). VII journée franco-africaines de pathologie. Niamey 11 au 13 février 2003

[22] BOTTOM, O'LEARY, SHEAFFER, PHILLIPS, SHU et al. Cancer Epidemiology in Older Adolescents and Young Adults 15 to 29 Years of Age, Including SEER Incidence and Survival: 1975-2000. National Cancer Institute, NIH Pub. No. 06-5767. Bethesda, MD 2006

[23] LD. MARRETT, J. FROOD, D. NISHRI, AM. UGNAT. Cancer incidence in young adults in Canada: preliminary results of a cancer surveillance project. 2002. Chronic Dis Can 23: $58-64$

[24] K. ZABICKI, J. COLBERT et al. Breast cancer diagnosis in women lower 40 versus 50 to 60 years: increasing size and stage disparity compared with older women over time. Annals of surgicaloncology 2006; 13: 1072-1077

[25] E. MATHIEU, P. MERVIEL, E. BARRANGER, J.M ANTOINE, S. UZAN. Journal de gynéco-obstétrique et de biologie de la reproduction. Paris

[26] A. BENDIB. Algérie: $12 \%$ des femmes atteintes du cancer du sein ont moins de 35 ans. http://www.algeriefocus.com/blog/2013/10/algerie-12-des-femmes-atteintes-ducancer-du-sein-ont-moins-de-35-ans/Par Djamila Ould Khettab| octobre 5, 2013.

[27] JR. CUAN MARTINEZ, FE. MAINERO RATCHELOUS, IU AGUILAR GALLEGOS, AB. MIRANDA, MA. BUENROSTRO PINEDA, IB. PORTILLO, A. EDELMIRA,
A. CORTES HERRERA, JJ. BURGUETE VERA. Comparacion de las caracteristicas de pacientes de 40 o menos y 70 anos omas de edad con carcinomamamario. GinecolObstetMex 2008. 76(6): 299-306

[28] HO ADAMI, B. MALKER, L. HOLMBERG, et al. The relation between survival and age at diagnosis and breast cancer.NEngl J Med.1986;315:559-563

[29] A. DE LA ROCHEFORDIERE, F. CAMPANA, J. FENTON, et al. Age as a prognostic factor in premenopausal breast cancer. Lancet. 1993; 341:1039-1043

[30] P. TAI, G. CSERNI, J. VAN DE STEENE, G. VLASTOS, M. VOORDECKERS, et al. Modeling the effect of age in T1-2 breast cancer using the SEER database. 2005. BMC Cancer 5: 130

[31] M. SANT, R. CAPOCACCIA, A. VERDECCHIA, J. ESTEVE, G. GATTA, et al. Survival of women with breast cancer in Europe: variation with age, year of diagnosis and country. The EUROCARE Working Group. 1998 Int J Cancer 77: 679-683

[32] HV. THOMAS, GK. REEVES, TJ. KEY. Endogenous estrogen and postmenopausal breast cancer: a quantitative review. Cancer Causes Control, 8: 922-928, 1997

[33] R. CLARKE, M. C LIU, K. B BOUKER, Z. GU, R. Y LEE, Y. ZHU, T. C SKAAR, GOMEZ. B, O'BRIEN. K, WANG. Y, A HILAKIVI-CLARKE. L. Antiestrogen resistance in breast cancer and the role of estrogen receptor signaling. Oncogene (2003) 22, 7316-7339

[34] RG. ZIEGLER. Anthropometry and breast cancer. J. Nutr, 127: 924S-928S, 1997.

[35] A. MCTIERNAN, C. ULRICH, S. SLATE, J. POTTER. Physical activity and cancer etiology: associations and mechanisms. Cancer Causes Control, 9: 487-509, 1998.

[36] CM. FRIEDENREICH, I. THUNE, LA. BRINTON, D. ALBANES. Epidemiologic issues related to the association between physical activity and breast cancer. Cancer (Phila.), 83(Suppl): 600-610, 1998

[37] B. MCAREE, ME.O'DONNELL, A. SPENCE, LIOE, TF. MCMANUS DT, RA.SPENCE. Breast cancer in women under 40 years of age: a series of 57 cases from Northern Ireland. Breast. 2010 Apr; 19(2):97-104. doi: 10.1016/j.breast.2009.12.002. Epub 2010. Jan.

[38] Elrasheid AH KHEIRELSEID, Jennifer ME BOGGS, Catherine CURRAN1, Ronan W GLYNN, Cara DOOLEY, Karl J SWEENEY and Michael J KERIN. Younger age as a prognostic indicator in breast cancer: A cohort study. BMC Cancer 2011, 11:383 doi: 10.1186/1471-2407-11-383.

[39] Ava KWONG, Polly CHEUNG, Stephanie CHAN, Silvia LAU. Breast Cancer in Chinese Women Younger than Age 40: Are They Different from Their Older Counterparts? World Journal of Surgery. December 2008, Volume 32, Issue 12, pp 2554-2561.

[40] Jp. BOURGEOIS. Traitement du cancer du sein. Rev. Prat. $1990 \mathrm{~N}^{\circ} 10$ : 914-916.

[41] L. PIANA, F. BONNIER. Tumeur du sein: Epidémiologie, dépistage, diagnostic, évolution, pronostic, principe du traitement. Rev. Prat. Paris; 1992,4211. 
[42] J. ROUESSE et al. Facteurs épidémiologique et pronostiques des cancers du sein. Rev. Prat. Paris: 1990; 40: 909-913.

[43] HY. AL-IDRISSI, EM. IBRAHIM, NY. KURASHI, SA. SOWAYAN: Breast Cancer in a Low Risk Population. The Influence of Age and Menstrual Status on Disease Pattern and Survival in Saudi Arabia. Int J Cancer 1992, 52:48-51.

[44] KS. CHIA, WB. DU, R. SANKILA, H. WANG, J. LEE, A. SEOW, HP. LEE: Do younger female breast cancer patients have a poorer prognosis? Results from a population-based survival analysis. Int J Cancer 2004, 108:761-765.

[45] E. RAPITI, G. FIORETTA, HM. VERKOOIJEN, G. VLASTOS, P. SCHAFER, AP. SAPPINO, J. KURTZ, I. NEYROUD-CASPAR, C. BOUCHARDY: Survival of young and older breast cancer patients in Geneva from 1990 to 2001. Eur J Cancer 2005, 41:1446-1452.

[46] DR. Pathak, JR. Osuch, He J. Breast carcinoma etiology: current knowledge and new insights into the effects of reproductive and hormonal risk factors in black and white populations. Cancer. 2000 Mar 1;88(5 Suppl):1230-8.

[47] J. ROBLES-CASTILLO, E. RUVALCABA-LIMON, A. MAFFUZ, S. RODRIGUE Z-CUEVAS. Cancer de mama en mujeres mexicanas menores de 40 anos. Ginecol Obstet Mex 2011; 79(8): 482-488.

[48] A. AYYAD et al. Cancer du sein chez la femme jeune de moins de 35 ans (a propos de 48 cas). Université Sidi Mohammed BEN ABDELLAH.FES.MAROC. 2010.

[49] C. FREUNDA, L. MIRABELA, K. ANNANE, C. MATHELIN . Allaitement maternel et cancer du sein. Gynécologie Obstétrique \& Fertilité. Vol 33, Issue 10, Oct 2005, P 739-744.

[50] N. Kroman, J. Wohlfahrt, KW. Andersen, et al. Time since childbirth and prognosis in primary breast cancer: population based study.BMJ 1997; 315: 851-855.

[51] Breast cancer and breastfeeding: collaborative reanalysis of individual data from 47 epidemiological studies in 30 countries, including 50302 woment with breast cancer and 96973 women without the disease. Collaborative Group on Hormonal Factors in Breast Cancer. Lancet 2002; 360:187-95.

[52] VF. Guinée, H. Olsson, T. Moller, et al. Effect of pregnancy on prognosis for young women with breast cancer. Lancet 1994; 343:1587-1589.

[53] I. Bouamama, Z. Bourhaleb, M. Moukhlissi, N. Benchakroun, H. Jouhadi, N. Tawfiq, S. Sahraoui, A. Benide. Le cancer du sein chez la femme jeune : particularités épidémiologiques, génétiques, pathologiques, biologiques et thérapeutiques. Doi:10.1016/j.canrad.2 009. 08.124.

[54] VF. Semiglazov, VN. Sagaidak, VM. Moiseyenko, EA. Mikhailov. Study of the role of breast self-examination in the reduction of mortality from breast cancer.The Russian Federation/ World Health Organization Study.Eur J Cancer. 1993; 29A (14): 2039-46.

[55] http://www.cancer.ca/fr-ca/cancerinformation/cancertype/breast/pathology-andstaging/malignant-tumours/inflammatory-breastcancer/?Region=bc\#ixzz 3EVSpUkhP.

[56] S. Thangjam, RS. Laishram, K. Debnath. Breast carcinoma in young females below the age of 40 years: A histopathological perspective. South Asian J Cancer 2014; 3: 97-100.
[57] EA. Rakha, Reis-Filho JS, Ellis IO. Basal-like breast cancer: A critical review. J ClinOncol 2008; 26:2568-81.

[58] CsabaGajdos .Paul I Tartter,Ira J Bleiweiss. Carol Bodian. Steven $\mathrm{T}$ Brower.Stage 0 to stage III breast cancer in young women. Journal of the American College of Surgeons. Volume 190, Issue 5, Pages 523-529, May 1, 2000.

[59] A. Bharat, Aft, R. L., Gao, F. and Margenthaler, J. A. (2009), Patient and tumor characteristics associated with increased mortality in young women $(\leq 40$ years $)$ with breast cancer.J.Surg.Oncol,100: 248-251.doi: 10.1002/jso.21268.

[60] Filomena M. Carvalho, Livia M. Bacchi, Priscila P. C. Santos, Carlos E. Bacchi. Triple-negative breast carcinomas are a heterogeneous entity that differs between young and old patients. Clinics vol. 65 no. 10 São Paulo 2010.

[61] Melinda A MAGGARD, Jessica B O'Connell, Karen E Lane, Jerome H Liu, David AEtzioni, Clifford Y Ko. Do young breast cancer patients have worse outcomes? Journal of Surgical Research.Volume 113, Issue 1, Pages 109-113, July 2003.

[62] Foo, C. S., Su, D., Chong, C. K., Chng, H. C., Tay, K. H., Low, S. C. and Tan, S. M. (2005), Breast cancer in young Asian women: Study on survival. ANZ Journal of Surgery, 75: 566572. doi: 10.1111/j.1445-2197.2005.03431.x.

[63] EBCTCG: Favourable and unfavourable effects on long-term survival of radiotherapy for early breast cancer: an overview of the randomised trials. Lancet 2000, 355(9217): 1757-1770.

[64] IH. Kunkler, Williams LJ, King CC, Jack W: Breast radiotherapy: considerations in older patients. Clinical Oncology 2009, 21(2): 111-117.

[65] O. Abe, Abe R, Enomoto K, Kikuchi K, Koyama H, Nomura Y, Sakai K, Sugimachi K, Tominaga T, Uchino J, et al. Polychemotherapy for early breast cancer: an overview of the randomised trials. Lancet 1998, 352(9132): 930-942.

[66] M. Kimura, Yanagita Y, Fujisawa T, Koida T: Study of timecourse changes in annual recurrence rates for breast cancer: Data analysis of 2,209 patients for 10 years post-surgery. Breast Cancer Research and Treatment 2007, 106(3): 407-411.

[67] N. Houssami, Irwig L, Simpson JM, McKessar M, Blome S, Noakes J. Sydney Breast Imaging Accuracy Study: Comparative sensitivity and specificity of mammography and sonography in young women with symptoms. AJR Am J Roentgenol. 2003;180(4):935-940).

[68] A. Sidoni, A. Cavaliere, G. Bellezza, M. Scheibel, E. Bucciarelli: Breast cancer in young women: clinicopathological features and biological specificity.Breast 2003,12(4): 247-250).

[69] L. Livi, I. Meattini I, C. Saieva, S. Borghesi, V. Scotti, A. Petrucci, A. Rampini, L. Marrazzo, V. Di Cataldo, S. Bianchi, et al. The impact of young age on breast cancer outcome.Eur $\mathbf{J}$ SurgOncol 2010).

[70] C. GOHFIB et al, Familial breast cancer: collaborative reanalysis of individual data from 52 espidemiological studies including 58209 woman with breast cancer and 101986 women without the disease. Lancet. 2001: 358 : 1389-99.

[71] J. GEST et al. Cancer du sein étiologie et histoire naturelle. EMC paris Gynéco 4,1975; 865. 